\title{
BMJ
}

\section{Interventions to promote cycling: systematic review}

\author{
Lin Yang, PhD student Shannon Sahlqvist, career development fellow Alison McMinn, career development \\ fellow Simon J Griffin, assistant director David Ogilvie, clinical investigator scientist
}

Medical Research Council

Epidemiology Unit and UK Clinical Research Collaboration Centre for

Diet and Activity Research

(CEDAR), Cambridge, UK

Correspondence to: D Ogilvie, UK

Clinical Research Collaboration

Centre for Diet and Activity

Research (CEDAR), Box 296,

Institute of Public Health, Forvie

Site, Robinson Way, CambridgeCB2

OSR, UK

david.ogilvie@mrc-epid.cam.ac.uk

Cite this as: $B M J$ 2010;341:c5293 doi:10.1136/bmi.c5293

\section{ABSTRACT}

Objectives To determine what interventions are effective in promoting cycling, the size of the effects of interventions, and evidence of any associated benefits on overall physical activity or anthropometric measures.

Design Systematic review.

Data sources Published and unpublished reports in any language identified by searching 13 electronic

databases, websites, reference lists, and existing systematic reviews, and papers identified by experts in the field.

Review methods Controlled "before and after" experimental or observational studies of the effect of any type of intervention on cycling behaviour measured at either individual or population level.

Results Twenty five studies (of which two were randomised controlled trials) from seven countries were included. Six studies examined interventions aimed specifically at promoting cycling, of which four (an intensive individual intervention in obese women, high quality improvements to a cycle route network, and two multifaceted cycle promotion initiatives at town or city level) were found to be associated with increases in cycling. Those studies that evaluated interventions at population level reported net increases of up to 3.4 percentage points in the population prevalence of cycling or the proportion of trips made by bicycle. Sixteen studies assessing individualised marketing of "environmentally friendly" modes of transport to interested households reported modest but consistent net effects equating to an average of eight additional cycling trips per person per year in the local population. Other interventions that targeted travel behaviour in general were not associated with a clear increase in cycling. Only two studies assessed effects of interventions on physical activity; one reported a positive shift in the population distribution of overall physical activity during the intervention.

Conclusions Community-wide promotional activities and improving infrastructure for cycling have the potential to increase cycling by modest amounts, but further controlled evaluative studies incorporating more precise measures are required, particularly in areas without an established cycling culture. Studies of individualised marketing report consistent positive effects of interventions on cycling behaviour, but these findings should be confirmed using more robust study designs. Future research should also examine how best to promote cycling in children and adolescents and through workplaces. Whether interventions to promote cycling result in an increase in overall physical activity or changes in anthropometric measures is unclear.

\section{INTRODUCTION}

Physical activity reduces the risk of cardiovascular disease, type 2 diabetes, some cancers, and a variety of other chronic conditions. ${ }^{1}$ An active lifestyle is, therefore, associated with lower all cause mortality and improved quality of life. ${ }^{2}$ It is recommended that adults should undertake at least 150 minutes of moderate intensity physical activity or 75 minutes of vigorous physical activity a week. ${ }^{3}$ Most adults in the United Kingdom and other developed countries do not currently achieve this target. ${ }^{4}$

Interventions to promote physical activity using a range of methods (such as individual face to face, group based, and mass communication techniques) in a variety of settings (such as schools, workplaces, and communities) have been evaluated in numerous studies. ${ }^{5-7}$ Many have focused on techniques for behaviour change that are applied to individuals in particular contexts (for example, primary care consultations) or populations (for example, people with a family history of type 2 diabetes). ${ }^{89}$ Although these approaches may be efficacious for some people in the short term, the evidence that they are effective in promoting sustained behaviour change in the population at large is limited. ${ }^{10}$

Factors influencing physical activity can be both behaviour specific and context specific. Different activities such as walking, gardening, or jogging could be more or less feasible or appealing for different people, and the likelihood of undertaking the same type of behaviour might vary according to the context (compare, for example, walking during a lunch break at work with going for a walk at the weekend). ${ }^{11} 12$ This suggests that interventions might be more effective when targeted at promoting particular forms of physical activity. ${ }^{12}$

Unlike many forms of exercise and leisure time physical activity, walking and cycling could be included in many people's daily routines as a means of travel from place to place. They might, therefore, be easier in principle to adopt and maintain than other forms of physical activity. Although walking could be a more accessible form of "active travel" for some people, ${ }^{13}$ 
cycling may be more likely to raise the heart rate sufficiently to improve cardiorespiratory fitness and has been shown to be associated with improved health outcomes for both young people and adults. ${ }^{14-17}$ Health professionals are increasingly being urged to encourage their patients to take up cycling. ${ }^{18}$

Cycling declined as a mode of transport in Britain between 1996 and 2007 despite the existence of a national cycling strategy. ${ }^{19}$ The aspiration to reverse this downward trend is now a recurring theme of government policy, ${ }^{20}$ not least because cycling offers a highly efficient substitute for short car trips of up to several miles. As such, promoting cycling could also help to reduce traffic congestion, air pollution, and carbon emissions. ${ }^{21}$

We systematically reviewed the available evidence to determine what approaches are effective in promoting cycling, the size of the effects observed, and evidence of any associated benefits on overall physical activity or anthropometric measures. We did not set out to review the evidence on distal health outcomes associated with cycling, which is addressed in a complementary body of literature. ${ }^{14-1722}$

\section{METHODS}

\section{Search strategy}

We searched for intervention studies with a cycling outcome measure in 13 electronic databases (AgeLine, CINAHL, Cochrane Library, Digital Dissertations, Embase, ERIC, Medline, PsycARTICLES, PsycINFO, TRIS, Sociological Abstracts, SportDiscus, and Web of Knowledge). We set no search limits on study design, study population, type of intervention, or language of publication. Our search syntax was, therefore, limited to terms for cycling and terms for interventions (see web table A). We also searched previous systematic reviews, websites, and reference lists of included papers. We then validated our list of included studies by asking a group of 20 international experts to identify any published or unpublished studies missed by our search strategy. We completed our search in January 2010.

\section{Study selection and inclusion criteria}

We included controlled trials and "before and after" experimental or observational studies of the effect of any type of intervention on cycling behaviour. Studies had to include a "do nothing" or "minimal intervention" control or comparison group, area, or population. An increase in cycling need not have been the primary aim of the intervention or the primary outcome measure for the study, but a specific measure of cycling both before and after the intervention was introduced was required at either individual or population level.

We excluded uncontrolled studies, cross sectional studies comparing the prevalence of cycling in areas with different environmental or policy characteristics, and studies with outcomes based on the use of stationary bicycles or bicycle ergometers rather than "real" cycling.
One reviewer removed obviously irrelevant references by screening titles and abstracts, with a 5\% sample of these decisions being verified by another reviewer. All remaining abstracts were assessed for inclusion by one reviewer, with all those selected for exclusion being checked by the other reviewers before final exclusion. The full text of all remaining studies was obtained and assessed independently for inclusion by two reviewers, with any discrepancies resolved in discussion with a third reviewer.

\section{Data extraction and assessment of study validity}

For each included study, one reviewer extracted data, a second reviewer verified the extracted data and made a summary assessment of study validity, and the first reviewer then verified the assessment of validity. Any discrepancies were resolved by discussion. Data that summarised the following factors were extracted: the country, setting, objective, and content of the intervention; the study design; the procedures for defining, recruiting, and sampling from the intervention and control groups; the frequency and duration of follow-up; the cycling outcome measures; the results of any statistical tests reported; and any evidence relating to effects on overall physical activity or anthropometric measures. Where studies had both controlled and uncontrolled components, cycling outcome data from uncontrolled analyses were not included.

We initially assessed study validity by using the following 11 criteria adapted from those used in previous reviews ${ }^{1323}$ : random allocation of intervention; blinding of intervention allocation status; response rate or representativeness of baseline sample; comparability of intervention and control groups or adjustment for differences in analysis; duration of follow-up; sample size at follow-up; follow-up rate (for cohort studies) or minimum achieved sample size per wave (for repeat cross sectional studies); blinding of outcome assessment; use of a validated or recognised outcome measure; adjustment of outcome assessment for baseline measures; and reporting of tests of statistical significance. We then summarised study validity by using the five binary criteria that most usefully discriminated between studies (randomisation, representativeness, comparability, measurement, and use of statistical test).

We summarised the outcomes for each study in terms of the net change in cycling after adjustment for changes observed in the control group. We presented results in terms of absolute rather than relative changes wherever possible and grouped outcomes by the type of metric used - such as the proportion of trips made by bicycle (mode share), bicycle trip frequency, or time spent cycling - in a quantitative narrative synthesis. Given the heterogeneity of the types of intervention, settings, study designs, and outcome metrics, and the failure of many studies to report basic statistical requirements such as standard deviations or confidence intervals, meta-analysis was neither feasible nor appropriate. ${ }^{24}$ 


\section{RESULTS}

We screened 27696 references and assessed the full text of 118 documents in four languages (figure). Twenty five controlled studies from seven countries (Australia, Denmark, Germany, the Netherlands, Sweden, the UK, and the United States) met our inclusion criteria, of which two were randomised controlled trials (tables 1, 2, and 3). The remainder of the 118 documents examined in full text were excluded (see web table B).

Six studies concerned interventions designed primarily or exclusively to promote cycling. Sixteen studies evaluated one particular approachindividualised marketing of "environmentally friendly" modes of transport (walking, cycling, and public transport) - in different locations. Only one study assessed an intervention targeted specifically at children. Most studies had comparatively large sample sizes, ranging from 60 to more than 1000 participants in each group. Studies used a variety of measures of cycling behaviour, most of which were self reported and of unknown validity or reliability. Two studies reported outcomes in terms of self reported overall physical activity and one reported objectively assessed anthropometric outcomes. Unless otherwise stated, significance tests reported in the text refer to tests of the difference between changes in cycling behaviour in the intervention group and changes in cycling behaviour in the control group.

Effects of interventions primarily to promote cycling Six studies (including two randomised controlled trials) examined the effects of interventions to promote cycling in particular, rather than those to promote non-car modes of transport in general (tables 1 and 4). All six studies met at least three of the five summary validity criteria (see web table $\mathrm{C}$ ).

One randomised controlled trial evaluated an intensive, theory based individual intervention to promote active commuting in women with abdominal obesity in Sweden. ${ }^{25}$ The intervention comprised three individual 30 minute meetings with a doctor, physical activity prescriptions, and the use of a free bicycle and accessories. Women in the intervention group were significantly more likely than those in the control

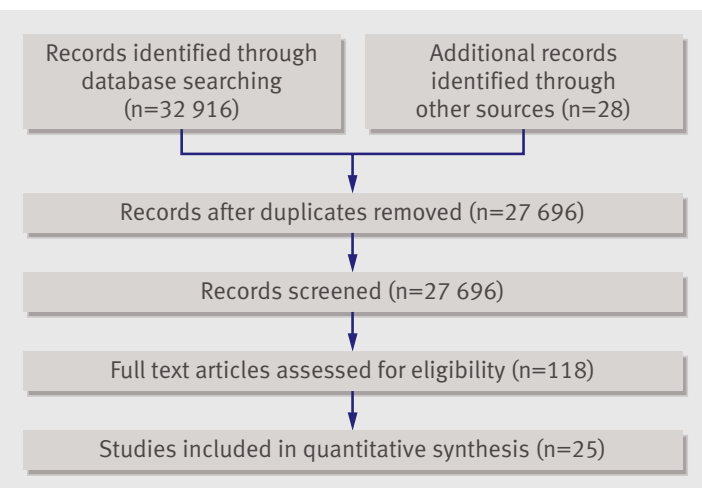

Study selection flow chart group to report cycling more than $2 \mathrm{~km}$ per day after 18 months (odds ratio 7.8, 95\% CI 4.0 to 15.0 ; $\mathrm{P}<0.001 ; 97 \%$ of randomised participants included in final intention to treat analysis). The difference between groups remained significant if cycling more than $4 \mathrm{~km}$ per day was used to define success of the intervention $(\mathrm{P}<0.001)$.

The BikeTexas Safe Routes to School intervention involved a combination of educational and promotional activities by teachers to motivate fourth and fifth grade students and their parents to walk and cycle to school. In a cluster randomised controlled trial, ${ }^{26}$ the intervention had no effect on cycling to school in intervention schools compared with control (waiting list) schools $(\mathrm{P}=0.68)$ but significantly increased the prevalence of recreational cycling after one semester (net increase +2.54 days/week, $\mathrm{P}=0.02$; follow-up rate $90 \%$ ).

A controlled repeat cross sectional study in the Dutch city of Delft examined the effects of improving the connectivity of the cycle route network in one area of the city. ${ }^{27}$ The proportion of household trips made by bicycle rose from $40 \%$ to $43 \%$ in the intervention area over a three year period and from $38 \%$ to $39 \%$ in a control area of the city.

The three year Danish National Cycle City project aimed to increase cycling in Odense between 1999 and 2002 through a multifaceted approach that included promotional campaigns and infrastructural measures. A controlled repeat cross sectional study comparing national travel survey data collected in Odense and in nearby towns and cities between 1996-97 and 2002 found an increase in the proportion of all trips made by bicycle in Odense from $22.5 \%$ to $24.6 \%$ (equating to an estimated net increase of 3.4 percentage points after adjustment for regional trends) and a net increase in the distance cycled of 100 metres per person per day. ${ }^{2829}$

The Cycling Demonstration Towns programme in England involved various combinations of town-wide media campaigns, personalised travel planning, cycle repair and cycle training services, and improvements to infrastructure for cycling. The effect of the first phase comprising six towns (2005 to 2008) was examined in a controlled repeat cross sectional study based on telephone surveys of quota samples of local residents. ${ }^{30}$ Net increases were found in the proportions of residents who reported cycling for at least 30 minutes once per month $(+2.78 \%$ or $+1.89 \%$, depending on the choice of control areas) or 12 or more times per month $(+0.97 \%$ or $+1.65 \%)$.

A community based social marketing programme involving information provision, cycle training, free bike hire, and a Ride To Work Day campaign aimed to promote the use of existing cycle paths in Sydney, Australia. In a controlled cohort study, residents of the intervention area were significantly more likely to report use of the cycle paths than residents of the control area at two year follow-up (absolute net change in prevalence $+5.1 \%$; $\mathrm{P}<0.01$; follow-up rate $72 \%) .{ }^{31}$ Data from bicycle counters showed increased use of the paths in both areas, with a significantly greater 
Table 1 |Characteristics of the included studies of interventions primarily to promote cycling

\begin{tabular}{|c|c|c|c|c|c|c|c|c|}
\hline Study & Country & Setting & Intervention & Control & $\begin{array}{c}\text { Study } \\
\text { population }\end{array}$ & Study design & $\begin{array}{l}\text { Period of } \\
\text { follow-up }\end{array}$ & $\begin{array}{c}\text { Sample } \\
\text { size* }^{\star}\end{array}$ \\
\hline Hemmingsson et al, $2009^{25}$ & Sweden & Community & $\begin{array}{l}\text { Intensive individual intervention, } \\
\text { based on the transtheoretical model } \\
\text { of behaviour change, that included } \\
\text { free bikes }\end{array}$ & $\begin{array}{l}\text { Low intensity group } \\
\text { support programme } \\
\text { that included } \\
\text { pedometers }\end{array}$ & $\begin{array}{l}\text { Women with } \\
\text { abdominal } \\
\text { obesity }\end{array}$ & $\begin{array}{l}\text { Randomised } \\
\text { controlled trial }\end{array}$ & 6 months & 99 \\
\hline Groesz, $2007^{26}$ & USA & School & $\begin{array}{l}\text { BikeTexas Safe Routes to School, } \\
\text { consisting of both educational and } \\
\text { motivational activities by teachers }\end{array}$ & $\begin{array}{l}\text { Waiting list schools } \\
\text { that received no } \\
\text { intervention }\end{array}$ & $\begin{array}{l}\text { Children in } \\
\text { primary schools }\end{array}$ & $\begin{array}{l}\text { Cluster } \\
\text { randomised } \\
\text { controlled trial }\end{array}$ & 5 months† & 107 \\
\hline
\end{tabular}
based on social cognitive theory,

theory of reasoned action, theory of planned behaviour, and social ecological models

\begin{tabular}{|c|c|c|c|c|c|c|c|c|}
\hline Wilmink and Hartman, $1987^{27}$ & Netherlands & City & $\begin{array}{l}\text { Cycle route network extended and } \\
\text { improved }\end{array}$ & $\begin{array}{l}\text { Comparison area of } \\
\text { city that received no } \\
\text { intervention }\end{array}$ & City residents & $\begin{array}{l}\text { Controlled repeat } \\
\text { cross sectional } \\
\text { study }\end{array}$ & 3 years $\ddagger$ & 2000 \\
\hline Troelsen et al, 2004-5 28,29 & Denmark & City & $\begin{array}{l}\text { Multifaceted urban initiative } \\
\text { (Danish National Cycle City project) }\end{array}$ & $\begin{array}{l}\text { Comparison areas that } \\
\text { received no } \\
\text { intervention }\end{array}$ & City residents & $\begin{array}{l}\text { Controlled repeat } \\
\text { cross sectional } \\
\text { study }\end{array}$ & 3 years $\ddagger$ & $\sim 1000$ \\
\hline Sloman et al, $2009^{30}$ & England & Towns & $\begin{array}{l}\text { Various combinations of town-wide } \\
\text { media campaigns, personalised } \\
\text { travel planning, cycle repair and } \\
\text { cycle training services, and } \\
\text { improvements to cycle } \\
\text { infrastructure }\end{array}$ & $\begin{array}{l}\text { Comparison local } \\
\text { authority areas that } \\
\text { received no } \\
\text { intervention }\end{array}$ & Adult residents & $\begin{array}{l}\text { Controlled repeat } \\
\text { cross sectional } \\
\text { study }\end{array}$ & 2 years $\ddagger$ & 710 \\
\hline Rissel et al, $2010^{31}$ & Australia & Community & $\begin{array}{l}\text { Social marketing of cycle } \\
\text { infrastructure based on } \\
\text { transtheoretical model of behaviour } \\
\text { change }\end{array}$ & $\begin{array}{l}\text { Comparison area that } \\
\text { received no } \\
\text { intervention }\end{array}$ & Adult residents & $\begin{array}{l}\text { Controlled cohort } \\
\text { study }\end{array}$ & 2 years $\ddagger$ & 909 \\
\hline
\end{tabular}

*Total number of participants in intervention and control groups combined at follow-up.

†Period of follow-up after completion of intervention.

$\ddagger$ Period of follow-up after inception of intervention (period of follow-up after completion either not reported or not applicable).

increase in the intervention area (net increase $+7.9 \%$ ), but no overall increase in the population prevalence of cycling was reported.

\section{Effects of individualised marketing of "environmentally friendly" modes of transport}

Sixteen studies examined the effects of individualised marketing on households in different locations, mostly in the UK but also in Australia and Germany (tables 2 and 4). ${ }^{32-53}$ These studies typically compared changes in self reported travel behaviour in representative samples of households in the intervention communities with changes in nearby control communities. Most studies in this group met two of the five summary validity criteria; only one met three (see web table C). Two were controlled cohort studies with follow-up rates of $84 \%$ and $67 \%$, respectively; the remainder were based on controlled repeat cross sectional designs, with response rates of at least $65 \%$ in most studies.

The interventions aimed to promote a shift from cars to environmentally friendly modes of transport (walking, cycling, and public transport) by providing information tailored to individual households' interests and requirements. Most studies evaluated a particular branded package (IndiMark), which provided various combinations of marketing materials, information (such as bus timetables and cycle maps), and incentives (such as free trial bus tickets) to households identified as interested in changing their travel behaviour.
In these studies, individualised marketing was associated with modest but generally consistent net increases in cycling trip frequency (range from 0 to +21 trips per person per year; median +8 ).

Effects of other interventions to change travel behaviour in general

Three other studies examined the effects of interventions to change travel behaviour in general rather than to promote cycling in particular (tables 2 and 4). None of these studies met more than one of the five summary validity criteria (see web table $\mathrm{C}$ ).

A controlled repeat cross sectional study examined the effect of City CarShare, a car sharing initiative in San Francisco, USA, whereby on payment of a small fee, members had access to car hire at a flat rate. Aspiring members, who were less likely to own or use cars at baseline than city residents as a whole, served as a "waiting list" control group. The study found a small decrease $(-3.4 \%)$ in the proportion of trips made by bicycle by club members over a period of 8-9 months, whereas the mode share in the control group increased $(+8.2 \%)$ during the same period, reflecting a net change of $-11.6 \% .^{54-56}$

A controlled repeat cross sectional study of a sustainable transport public awareness campaign involving leaflets, mass media, exhibitions and talks in schools in the context of improvements to local transport infrastructure in Maidstone, UK, reported a significant 
Table 2 |Characteristics of the included studies on individualised marketing of "environmentally friendly" modes of transport (walking, cycling, and public transport)

\begin{tabular}{|c|c|c|c|}
\hline Study & Country & Setting & Intervention \\
\hline Haq et al, $2004^{32}$ & England & Community & $\begin{array}{l}\text { Individualised marketing } \\
\text { along similar lines to } \\
\text { IndiMark (see below) }\end{array}$ \\
\hline $\begin{array}{l}\text { TravelSmart Brisbane (Marinelli } \\
\text { and Roth), } 2002^{33}\end{array}$ & Australia & Community & $\begin{array}{l}\text { Individualised marketing } \\
\text { (IndiMark): provision of } \\
\text { tailored information, } \\
\text { advice, and incentives to } \\
\text { encourage change in travel } \\
\text { behaviour in interested } \\
\text { households }\end{array}$ \\
\hline
\end{tabular}

\begin{tabular}{|c|c|c|c|c|c|c|c|c|}
\hline $\begin{array}{l}\text { Viernheim Household Transport } \\
\text { (TAPESTRY), } 2003^{34}\end{array}$ & Germany & Community & IndiMark (see above) & $\begin{array}{l}\text { Comparison area that } \\
\text { received no intervention }\end{array}$ & Households & $\begin{array}{l}\text { Controlled repeat } \\
\text { cross sectional study }\end{array}$ & 6 or 8 months $\dagger$ & 987 \\
\hline $\begin{array}{l}\text { TravelSmart Perth (Department for } \\
\text { Planning and Infrastructure, } \\
\text { Government of Western Australia), } \\
2003^{35-37}\end{array}$ & Australia & Community & IndiMark (see above) & $\begin{array}{l}\text { Comparison area that } \\
\text { received no intervention }\end{array}$ & Households & $\begin{array}{l}\text { Controlled repeat } \\
\text { cross sectional study }\end{array}$ & 6 months $†$ & 1959 \\
\hline $\begin{array}{l}\text { TravelSmart Frome (Sustrans), } \\
2002^{38,39}\end{array}$ & England & Community & IndiMark (see above) & $\begin{array}{l}\text { Comparison area that } \\
\text { received no intervention }\end{array}$ & Households & $\begin{array}{l}\text { Controlled repeat } \\
\text { cross sectional study }\end{array}$ & 2-3 months $†$ & 749 \\
\hline $\begin{array}{l}\text { TravelSmart Gloucester (Sustrans), } \\
2004^{40-42}\end{array}$ & England & Community & IndiMark (see above) & $\begin{array}{l}\text { Comparison area that } \\
\text { received no intervention }\end{array}$ & Households & $\begin{array}{l}\text { Controlled repeat } \\
\text { cross sectional study }\end{array}$ & $\begin{array}{l}3 \text { and } \\
8 \text { monthst }\end{array}$ & 889 \\
\hline $\begin{array}{l}\text { TravelSmart Nottingham } \\
\text { (Sustrans), } 2004^{43}\end{array}$ & England & Community & IndiMark (see above) & $\begin{array}{l}\text { Comparison area that } \\
\text { received no intervention }\end{array}$ & Households & $\begin{array}{l}\text { Controlled repeat } \\
\text { cross sectional study§ }\end{array}$ & 6 months $†$ & 1337 \\
\hline $\begin{array}{l}\text { TravelSmart Sheffield (Sustrans), } \\
2004^{44}\end{array}$ & England & Community & IndiMark (see above) & $\begin{array}{l}\text { Comparison area that } \\
\text { received no intervention }\end{array}$ & Households & $\begin{array}{l}\text { Controlled repeat } \\
\text { cross sectional study§ }\end{array}$ & $\begin{array}{l}3 \text { and } \\
9 \text { monthst }\end{array}$ & 986 \\
\hline $\begin{array}{l}\text { TravelSmart Melville (Socialdata } \\
\text { Australia), } 2004^{45}\end{array}$ & Australia & Community & IndiMark (see above) & $\begin{array}{l}\text { Comparison area that } \\
\text { received no intervention }\end{array}$ & Households & $\begin{array}{l}\text { Controlled repeat } \\
\text { cross sectional study }\end{array}$ & 6 months $†$ & 589 \\
\hline $\begin{array}{l}\text { TravelSmart Bishopston (Sustrans), } \\
2004^{46}\end{array}$ & England & Community & IndiMark (see above) & $\begin{array}{l}\text { Comparison area that } \\
\text { received no intervention }\end{array}$ & Households & $\begin{array}{l}\text { Controlled repeat } \\
\text { cross sectional study§ }\end{array}$ & $\begin{array}{l}3 \text { and } \\
9 \text { monthst }\end{array}$ & 993 \\
\hline $\begin{array}{l}\text { TravelSmart Cramlington } \\
\text { (Sustrans), } 2004^{47}\end{array}$ & England & Community & IndiMark (see above) & $\begin{array}{l}\text { Comparison area that } \\
\text { received no intervention }\end{array}$ & Households & $\begin{array}{l}\text { Controlled repeat } \\
\text { cross sectional study§ }\end{array}$ & $\begin{array}{l}3 \text { and } \\
9 \text { months } †\end{array}$ & 796 \\
\hline $\begin{array}{l}\text { Travel Options Kingston } \\
\text { (Socialdata), } 2004^{48}\end{array}$ & England & Community & IndiMark (see above) & $\begin{array}{l}\text { Comparison area that } \\
\text { received no intervention }\end{array}$ & Households & $\begin{array}{l}\text { Controlled repeat } \\
\text { cross sectional study }\end{array}$ & $\begin{array}{l}1 \text { and } \\
10 \text { months } \dagger\end{array}$ & 693 \\
\hline $\begin{array}{l}\text { TravelSmart Doncaster (Socialdata, } \\
\text { Sustrans), } 2007^{49}\end{array}$ & England & Community & IndiMark (see above) & $\begin{array}{l}\text { Comparison area that } \\
\text { received no intervention }\end{array}$ & Households & $\begin{array}{l}\text { Controlled repeat } \\
\text { cross sectional study }\end{array}$ & 3 months & 1871 \\
\hline $\begin{array}{l}\text { TravelSmart East Inverness } \\
\text { (Socialdata, Sustrans), } 2008^{50}\end{array}$ & Scotland & Community & IndiMark (see above) & $\begin{array}{l}\text { Comparison area that } \\
\text { received no intervention }\end{array}$ & Households & $\begin{array}{l}\text { Controlled repeat } \\
\text { cross sectional study }\end{array}$ & 6 months $\dagger$ & 1129 \\
\hline $\begin{array}{l}\text { TravelSmart Lancashire } \\
\text { (Socialdata, Sustrans), 2006- } 7^{51,52}\end{array}$ & England & Community & IndiMark (see above) & $\begin{array}{l}\text { Comparison area that } \\
\text { received no intervention }\end{array}$ & Households & $\begin{array}{l}\text { Controlled repeat } \\
\text { cross sectional study }\end{array}$ & Variable & 811 \\
\hline $\begin{array}{l}\text { TravelSmart Gloucester (Barton, } \\
\text { Tredworth, and White City; }\end{array}$ & England & Community & IndiMark (see above) & $\begin{array}{l}\text { Comparison area that } \\
\text { received no intervention }\end{array}$ & Households & $\begin{array}{l}\text { Controlled repeat } \\
\text { cross sectional study }\end{array}$ & 6 months $\dagger$ & 1403 \\
\hline
\end{tabular}

Sustrans), $2006^{53}$

*Total number of participants in intervention and control groups combined at follow-up.

†Period of follow-up after completion of intervention.

$\ddagger$ Period of follow-up after inception of intervention (period of follow-up after completion either not reported or not applicable).

$\S$ Study involved elements of both repeated cross sectional and cohort designs.

decrease in the frequency of cycle trips in both intervention $(\mathrm{P}<0.05)$ and control $(\mathrm{P}<0.10)$ areas over a two year period, with a small net increase of +0.17 cycle trips per person per week in the intervention area. ${ }^{57}$

A controlled repeat cross sectional study of the effects of subsidising employees who chose not to commute to work by car in California, USA, reported a slight $(0.1 \%)$ increase in the proportion of trips made by bicycle at follow-up in eight intervention workplaces in contrast to a modest decrease in one control workplace, resulting in a net change of $+1.1 \% .{ }^{5859}$

\section{Effects on overall physical activity and anthropometric measures}

In the randomised controlled trial conducted in women with abdominal obesity, despite a greater increase in cycling in the intervention group, both groups achieved similar reductions in waist circumference $(-2.1 \mathrm{~cm}$ and $-2.6 \mathrm{~cm}$, respectively; $\mathrm{P}=0.72)$ and sagittal abdominal diameter $(-1.0 \mathrm{~cm}$ and $-1.1 \mathrm{~cm}$; no $\mathrm{P}$ value reported) after six months. ${ }^{25}$ These changes were maintained at 18 months.

The study of the Cycling Demonstration Towns used the European Prospective Investigation into Cancer and Nutrition (EPIC) physical activity index, a four point categorical measure of self reported overall physical activity. ${ }^{60}$ Three years after the baseline survey, the proportion of residents in the intervention areas categorised as inactive had significantly decreased $(-2.6 \%, 95 \%$ CI $-3.7 \%$ to $-1.5 \%)$, with corresponding increases in the proportions categorised as moderately inactive $(+3.2 \%, 95 \%$ CI $+2.2 \%$ to $+4.2 \%)$ and 
Table $3 \mid$ Characteristics of the included studies on interventions to change travel behaviour in general

\begin{tabular}{|c|c|c|c|c|c|c|c|c|}
\hline Study & Country & Setting & Intervention & Control & Study population & Study design & $\begin{array}{l}\text { Period of } \\
\text { follow-up }\end{array}$ & $\begin{array}{l}\text { Sample } \\
\text { size* }^{\star}\end{array}$ \\
\hline Cervero et al, $2002^{54-56}$ & USA & Community & $\begin{array}{l}\text { City CarShare caresharing club: members } \\
\text { paid monthly fee, deposit, and fixed rate } \\
\text { for car hire }\end{array}$ & $\begin{array}{l}\text { Waiting list control } \\
\text { group comprising } \\
\text { people who had signed } \\
\text { up to join but had not yet } \\
\text { become full members }\end{array}$ & $\begin{array}{l}\text { Members and } \\
\text { aspiring members }\end{array}$ & $\begin{array}{l}\text { Controlled repeat } \\
\text { cross sectional } \\
\text { study }\end{array}$ & 9 months† & 220 \\
\hline Hodgson et al, $1998^{57}$ & England & Community & $\begin{array}{l}\text { Marketing campaign, based on theory of } \\
\text { planned behaviour, that involved leaflets, } \\
\text { exhibitions, and talks to raise awareness } \\
\text { of environmental effects of motor } \\
\text { transport and of alternative modes, in the } \\
\text { context of improvements to local } \\
\text { transport infrastructure }\end{array}$ & $\begin{array}{l}\text { Households in } \\
\text { comparison area that } \\
\text { received no intervention }\end{array}$ & Households & $\begin{array}{l}\text { Controlled repeat } \\
\text { cross sectional } \\
\text { study }\end{array}$ & 2 years $\dagger$ & 1218 \\
\hline Shoup, $1997^{58,59}$ & USA & Workplace & $\begin{array}{l}\text { Cash subsidy offered by employers to staff } \\
\text { who did not require a parking space }\end{array}$ & $\begin{array}{l}\text { One comparison } \\
\text { workplace that did not } \\
\text { implement the policy }\end{array}$ & Employees & $\begin{array}{l}\text { Controlled repeat } \\
\text { cross sectional } \\
\text { study }\end{array}$ & $1-3$ years $†$ & 1807 \\
\hline
\end{tabular}

*Total number of participants in intervention and control groups combined at follow-up.

†Period of follow-up after inception of intervention (period of follow-up after completion either not reported or not applicable).

moderately active $(+1.3 \%, 95 \% \mathrm{CI}+0.3 \%$ to $+2.3 \%)$ but not in the proportion categorised as active. ${ }^{30}$ No comparative data for control areas were available.

The study of the marketing of existing cycle paths in Australia found increases in the mean total quantity of self reported physical activity in both the intervention area (from 210.9 to $242.2 \mathrm{~min} /$ week) and the control area (from 234.1 to $260.7 \mathrm{~min} /$ week); there was no significant difference between areas. ${ }^{31}$

\section{DISCUSSION}

\section{Principal findings}

We systematically reviewed all available controlled studies of the effects of interventions on cycling behaviour. The approaches studied ranged from intensive support directed at individuals ${ }^{25}$ to improving the infrastructure for cycling in urban environments, ${ }^{27}$ with many of the community level interventions comprising multifaceted packages of measures. The multiple studies that assessed individualised marketing of environmentally friendly modes of transport reported an average net effect of around eight additional cycling trips per person per year in the local populations targeted. A smaller number of studies found that interventions aimed specifically at promoting cycling (intensive individual intervention, improving or marketing infrastructure for cycling, or multifaceted town level or city level programmes) were associated with positive effects. Those interventions applied at population level were associated with net increases of up to 3.4 percentage points in the population prevalence of cycling or the proportion of trips made by bicycle. Three other studies of interventions that aimed to change travel behaviour in general found slight or no evidence of an increase in cycling.

Most studies included in the review did not report the statistical significance of any net increases in cycling. Furthermore, in most studies it is unclear whether such increases reflect new trips by infrequent or novice cyclists (which could represent early evidence of potential public health benefits) or additional trips by existing cyclists (which are less likely to contribute significant public health benefits).

\section{Comparison with other studies}

The wider literature on mostly uncontrolled studies in this field has recently been reviewed by Pucher and colleagues. ${ }^{61}$ Although their review illustrates the potential for achieving substantial increases in cycling over time, it was not a systematic review and it drew on a diverse range of evidence, including studies of stated preference but very few longitudinal studies of actual behaviour. Our review, therefore, provides a more realistic indication of the likely proximal behavioural effects of specific interventions.

\section{Strengths and limitations of the review}

The main strengths of this review are its exhaustive literature search and its inclusive approach to the type of interventions examined. We searched 13 literature databases across a wide range of disciplines, imposing as few limits as possible on our search and inviting experts to add to our list of included studies.

A number of studies reported additional uncontrolled "before and after" data that support a general conclusion that the interventions were effective. Uncontrolled data of this kind have sometimes attracted more attention in summary reports, media coverage, and review articles than have controlled data. Having initially examined both controlled and uncontrolled studies retrieved by our original literature search, we decided to restrict our analysis to controlled studies. Our review, with its emphasis on synthesising controlled (rather than uncontrolled) comparisons and absolute (rather than relative) effect sizes, suggests rather more modest public health effects of the interventions (table 4). Although restricting the review to controlled studies limited the range of interventions finally included in the review, we considered it an important step in eliminating one of the major sources of potential bias in estimating effect sizes, namely failure to adjust for any changes that would have occurred in the absence of the intervention.

Even after the elimination of uncontrolled studies, significant reservations remain about other potential sources of bias or confounding in most studies, and, 
Table 4 | Summary of net effects of interventions on cycling

\begin{tabular}{|c|c|c|c|c|}
\hline & $\begin{array}{l}\text { Proportion of all } \\
\text { trips made by cycle } \\
\text { (percentage point } \\
\text { change) } \dagger\end{array}$ & $\begin{array}{l}\text { Cycling trip } \\
\text { frequency per } \\
\text { person }\end{array}$ & $\begin{array}{l}\text { Distance } \\
\text { cycled per } \\
\text { person }\end{array}$ & $\begin{array}{l}\text { Cycling } \\
\text { time per } \\
\text { person per } \\
\text { day }\end{array}$ \\
\hline Interventions primarily to promote cycling & & & & \\
\hline
\end{tabular}

Hemmingsson et al, $2009^{25}$

\begin{tabular}{lccc}
\hline Groesz, $2007^{26}$ & 0 & & \\
\hline Wilmink and Hartman, $1987^{27}$ & +2 & $+4 \%$ & $+8 \%$ \\
\hline Troelsen et al, $2004-5^{28,29}$ & +3.4 & $+0.06 /$ day & $+0.1 \mathrm{~km} /$ day \\
\hline
\end{tabular}

Sloman et al, $2009^{30}$

Rissel et al, $2010^{31}$

Individualised marketing of "environmentally friendly" modes of transport

\begin{tabular}{|c|c|c|c|c|}
\hline Haq et al, $2004^{32}$ & 0 & $-0.7 /$ week & $+9 \mathrm{~km} /$ week & Bicycle users: +5 \\
\hline TravelSmart Brisbane, $2002^{33}$ & & $+1 /$ year & & \\
\hline $\begin{array}{l}\text { Viernheim Household Transport } \\
\text { (TAPESTRY), } 2003^{34}\end{array}$ & +2 & $+13 /$ year & & \\
\hline TravelSmart Perth, $2003^{35-37}$ & +1 & $+14 /$ year & $+1 \min$ & \\
\hline TravelSmart Frome, $2002^{38,39}$ & +1 & $+3 /$ year & & \\
\hline TravelSmart Gloucester, $2004^{40-42}$ & $+1 \ddagger$ & $+7 /$ year & 0 & \\
\hline TravelSmart Nottingham, $2004^{43}$ & +1 & $\begin{array}{l}+6 / \text { year and } \\
+12 / \text { year }\end{array}$ & 0 & \\
\hline TravelSmart Sheffield, $2004^{44}$ & 0 & $+2 /$ year & 0 & \\
\hline TravelSmart Melville, $2004^{45}$ & +2 & $+9 /$ year & 0 & \\
\hline TravelSmart Bishopston, $2004^{46}$ & +1 & $+15 /$ year & 0 & \\
\hline TravelSmart Cramlington, $2004^{47}$ & $0 \ddagger$ & $+4 /$ year & 0 & \\
\hline Travel Options Kingston, $2004^{48}$ & $+2 \ddagger$ & $\begin{array}{l}+21 / \text { year and } \\
+14 / \text { year } \uparrow\end{array}$ & 0 & \\
\hline TravelSmart Doncaster, $2007^{49}$ & +1 & $+3 /$ year & 0 & \\
\hline TravelSmart East Inverness, $2008^{50}$ & +1 & +9/year & 0 & \\
\hline TravelSmart Lancashire, 2006-7 51,52 & +1 and $+2 \S$ & $\begin{array}{l}+1 / \text { year, }+6 / \\
\text { year, and }+20 / \\
\text { year§ }\end{array}$ & $+1 \mathrm{~min}$ & \\
\hline $\begin{array}{l}\text { TravelSmart Gloucester (Barton, } \\
\text { Tredworth and White City), } 2006^{53}\end{array}$ & +1 & $+8 /$ year & $+1 \min$ & \\
\hline \multicolumn{5}{|c|}{ Interventions to change travel behaviour in general } \\
\hline Cervero et al, $2002^{54-56}$ & -2.7 and $-11.6 \pi$ & & & \\
\hline Hodgson et al, $1998^{57}$ & & $+0.17 /$ week & & \\
\hline Shoup, $1997^{58,59}$ & +1.1 & & & \\
\hline \multicolumn{5}{|c|}{$\begin{array}{l}\text { *Change observed in the intervention group after adjustment for change observed in the control group. } \\
\text { †Change, in absolute percentage points, in the proportion of all trips that were made by bicycle. } \\
\text { †Same results for first and second rounds of follow-up. } \\
\text { §Different results for different geographical areas within the overall study. } \\
\text { ๆDifferent results for first and second rounds of follow-up. }\end{array}$} \\
\hline
\end{tabular}

Prevalence of cycling $\geq 30$ min once a month or more: $+2.78 \%(+1.89 \%$ if adjusted to most similar control area) Prevalence of cycling $\geq 30$ min 12 times a month or more: $+0.97 \%(+1.65 \%$
if adjusted to most similar control area) if adjusted to most similar control area)

Prevalence of cycling in past year: $-0.5 \%$

Self reported prevalence of use of cycle paths: $+5.1 \%$ (P<0.001)

Number of bicycles counted: $+7.9 \%(P=0.021)$ Prevalence of cycling $>4 \mathrm{~km} /$ day at follow-up: $24.8 \%$ v $4.6 \%$ (P<0.001) Mean number of days cycled to school: no significant difference Recreational cycling: +2.54 days/week $(P=0.02)$

Outcomes*

Prevalence of cycling >2 km/day at follow-up: $38.7 \%$ v 8.9\% (OR 7.8, 95\%

Prevalence of cycling $\geq 30$ min once a month or more: $+2.78 \%(+1.89 \%$ if

(n)

therefore, in the interpretation of their results. These reservations include the reliance of many studies on self reported measures of cycling that are widely accepted but are of unknown validity and reliability, and the lack of clarity in many studies about the method of adjustment for changes in the control group. It is admittedly challenging to identify satisfactory control groups for area based interventions. ${ }^{62}$ Nonetheless, although it is possible to adjust in analysis for differences in important characteristics between intervention and control groups, most studies did not report whether or how this had been done.

\section{Implications for research, policy, and practice}

In contrast to a previous systematic review of interventions to promote walking, ${ }^{13}$ in our review most of the evidence of effectiveness of interventions to promote cycling was derived from interventions applied 
at a relatively large scale (that is, to whole communities or municipalities). In principle, such approaches may have greater potential effect on the general population than more individually focused interventions, particularly given that some of these studies reported beneficial effects up to three years after the inception of the interventions. However, although the evidence does suggest that a variety of approaches have clear potential to promote cycling, from a population perspective the effect sizes attributable to the interventions studied to date appear relatively modest.

There is evidently little agreement on how cycling behaviour should be measured. The variety of metrics used makes it difficult to compare interventions because the public health implications of, for example, an increase in mean daily cycling time are not necessarily the same as those of an increase in the proportion of trips made by bicycle (which could reflect nothing more than a decrease in the use of other modes of transport, including walking). Developing a degree of interdisciplinary consensus on approaches to measurement (including objective measurement) and evaluation is a challenging but important objective to be met if future studies are to provide a stronger evidence base to inform decision making across the health, transport, and planning sectors. ${ }^{63}$

On the basis of current evidence, the relation between changes in cycling behaviour and changes in overall physical activity directly attributable to interventions is unclear. It could be that individuals who increase their cycling activity in response to interventions applied to whole populations are already sufficiently physically active, or that the increase in cycling displaces other forms of physical activity. The recent study of the Cycling Demonstration Towns in England has reported a relation between an increase in

\section{WHAT IS ALREADY KNOWN ON THIS TOPIC}

Physical activity reduces the risk of cardiovascular disease, diabetes, and premature mortality, but most adults in the United Kingdom and other developed countries are not sufficiently active to achieve these health benefits

Cycling is a form of physical activity that could be incorporated into many people's daily routines as a mode of transport, resulting in both health and environmental benefits

Numerous systematic reviews have addressed the question of how to promote physical activity in general, but none has examined the effects of interventions to promote cycling as a specific physical activity behaviour

\section{WHAT THIS STUDY ADDS}

Controlled studies have shown that a variety of approaches are associated with increases in cycling, such as an intensive intervention with individuals, individualised marketing to households, improving infrastructure for cycling, and multifaceted town level or city level programmes

Overall, the available evidence on interventions to promote cycling is of limited quantity and validity, and suggests that such interventions produce relatively modest absolute increases in cycling at population level

Future research should incorporate more robust measures of cycling and should evaluate interventions delivered through schools and workplaces, the interaction between behavioural approaches and environmental changes, and the relation between changes in cycling and changes in overall physical activity cycling and a positive shift in the distribution of overal physical activity in the targeted local populations. ${ }^{30}$ However, in view of the repeat cross sectional design and lack of control data on physical activity in the study, this finding should be regarded as providing only preliminary evidence of a direct association and the association should be tested more rigorously in future studies to assess the realistic public health effect of interventions to promote active travel. Recent National Institute for Health and Clinical Excellence (NICE) guidance has highlighted research priorities in this area; for example, the need for such studies to include "appropriate and valid measures, including measures of overall physical activity levels before and after an intervention." ${ }^{64}$ Several studies incorporating such measures are under way. ${ }^{636566}$

There is nevertheless a strong case for promoting cycling on health grounds. Although we did not set out to directly examine the evidence for the health benefits of cycling, a complementary body of literature supports this assertion. At the individual level, cycling to work or school has been shown to be associated with greater cardiorespiratory fitness in adults ${ }^{15}$ and children, ${ }^{14}$ respectively, and in the Copenhagen City Heart Study cycling to work was associated with a significant reduction in mortality even after adjustment for leisure time physical activity (relative risk 0.72) ${ }^{17}$ At the population level, two recent studies modelling the health effects of a population shift towards active travel have independently concluded that the health benefits attributable to greater use of physically active modes of transport substantially outweigh any adverse effects related to risk of injury or exposure to inhaled pollutants. ${ }^{2067}$ Promoting cycling is, therefore, a viable approach to improving health.

Further development and evaluation of school based interventions is warranted, particularly in light of evidence that children who walk or cycle to school are more likely to be sufficiently physically active overall $^{68}$ and that active travel may represent a significant proportion of children's overall physical activity. ${ }^{69}$ School based interventions, including those with a family or community component, have been shown to be effective in promoting physical activity in children and adolescents, and similar approaches may be applicable to promoting cycling in particular. ${ }^{6}$ The workplace is another important potential setting for the promotion of active travel, ${ }^{7071}$ but it remains relatively under-researched with respect to cycling in particular. ${ }^{72} 73$

\section{Conclusions}

Evidence from observational studies suggests that changing the built environment has the potential to influence cycling behaviour, ${ }^{64}$ but few data from controlled intervention studies are currently available to confirm this. Our review shows that it is unclear whether increases in cycling could be achieved at lower cost by addressing attitudes and perceptions about cycling. 
Although individualised marketing of interventions to change travel behaviour appears to be effectiveincluding in areas of Australia and the UK with little in the way of an established cycling culture - this approach is only applicable to people who are already interested in changing their behaviour. The claims made about the effectiveness of this approach should ideally be tested in an independent randomised controlled trial. ${ }^{13}$ At the same time, lack of supportive infrastructure might limit the willingness of people to take up cycling, ${ }^{70}$ particularly in areas without an established cycling culture.

A strategy of changes to the environment combined with advice and support at both individual and institutional levels may, therefore, be required to bring about substantial and sustained changes in travel behaviour in the population. Approaches shown to have promise in this systematic review should continue to be developed and implemented in order that more rigorous evidence of their benefits can be accumulated. For interventions not amenable to study in a randomised trial, a variety of alternative quasiexperimental study designs could be appropriate. These approaches should include assessment of intervention processes and mechanisms as well as outcomes, and should adhere to guidance for the clear reporting of observational studies. ${ }^{74}$

We thank the group of experts who responded to our request to identify additional studies for inclusion in the review.

Contributors: All authors contributed to the design of the review protocol. LY executed the search strategy and screened the initial results of the literature searches. All authors contributed to selecting the studies for inclusion, appraising and extracting data from the included studies, and analysing and interpreting the findings. LY and DO drafted the manuscript. All authors contributed to the critical revision of the manuscript and approved the final version. DO is guarantor

Funding: This work was supported by the Centre for Diet and Activity Research (CEDAR), a UK Clinical Research Collaboration (UKCRC) Public Health Research Centre of Excellence. Funding from the British Heart Foundation, the Economic and Social Research Council, the Medical Research Council, the National Institute for Health Research (NIHR), and the Wellcome Trust, under the auspices of the UK Clinical Research Collaboration, is gratefully acknowledged (www.esrc.ac.uk/ publichealthresearchcentres). SJG also receives support from the Department of Health NIHR Programme Grant funding scheme (RP-PG0606-1259). The views expressed in this publication are those of the authors and not necessarily those of the Department of Health or other funders.

Competing interests: All authors have completed the Unified Competing Interest form at www.icmje.org/coi_disclosure.pdf (available on request from the corresponding author) and declare that all authors had: (1) No financial support for the submitted work from anyone other than their employer and the other funding sources listed above; (2) No financial relationships with commercial entities that might have an interest in the submitted work; (3) No spouses, partners, or children with relationships with commercial entities that might have an interest in the submitted work; (4) No non-financial interests that may be relevant to the submitted work other than their involvement in current primary research in the topic area of the systematic review.

Ethical approval: Not required

Data sharing: No additional data available.

1 Chief Medical Officer. At least five a week: evidence on the impact of physical activity and its relationship to health. Department of Health, 2004.

2 Physical activity and health: a report of the US Surgeon General. US Department of Health and Human Services, Centers for Disease Control and Prevention, National Center for Chronic Disease Prevention and Health Promotion, 1996.

3 US Department of Health and Human Services. Physical activity guidelines for Americans. Department of Health and Human Services, 2008.
4 Sproston K, Primatesta P. Health survey for England 2003. Stationery Office, 2004.

5 Kahn EB, Ramsey LT, Brownson RC, Heath GW, Howze EH, Powell KE, et al. The effectiveness of interventions to increase physical activity: a systematic review. Am J Prev Med 2002;22(suppl 4):73-107S.

6 Van Sluijs EM, McMinn AM, Griffin SJ. Effectiveness of interventions to promote physical activity in children and adolescents: systematic review of controlled trials. BMJ 2007;335:703.

7 Foster $\mathrm{C}$, Hillsdon M, Thorogood M. Interventions for promoting physical activity. Cochrane Database Syst Rev 2005;1:CD003180.

8 Kinmonth AL, Wareham NJ, Hardeman W, Sutton S, Prevost AT, Fanshawe T, et al. Efficacy of a theory-based behavioural intervention to increase physical activity in an at-risk group in primary care (ProActive UK): a randomised trial. Lancet 2008;371:41-8.

9 Williams K, Prevost AT, Griffin S, Hardeman W, Hollingworth W, Spiegelhalter D, et al. The ProActive trial protocol—a randomised controlled trial of the efficacy of a family-based, domiciliary intervention programme to increase physical activity among individuals at high risk of diabetes [ISRCTN61323766]. BMC Public Health 2004;4:48.

10 Müller-Riemenschneider F, Reinhold T, Nocon M, Willich SN. Longterm effectiveness of interventions promoting physical activity: a systematic review. Prev Med 2008;47:354-68.

11 Owen N, Humpel N, Leslie E, Bauman A, Sallis JF. Understanding environmental influences on walking: review and research agenda. Am J Prev Med 2004;27:67-76.

12 Baranowski T, Anderson C, Carmack C. Mediating variable framework in physical activity interventions. How are we doing? How might we do better? Am J Prev Med 1998;15:266-97.

13 Ogilvie D, Foster CE, Rothnie H, Cavill N, Hamilton V, Fitzsimons CF, et al. Interventions to promote walking: systematic review. $B M$ J 2007;334:1204-7.

14 Cooper AR, Wedderkopp N, Jago R, Kristensen PL, Moller NC, Froberg K, et al. Longitudinal associations of cycling to school with adolescent fitness. Prev Med 2008;47:324-8.

15 De Geus B, Joncheere J, Meeusen R. Commuter cycling: effect on physical performance in untrained men and women in Flanders: minimum dose to improve indexes of fitness. Scand I Med Sci Sports 2009;19:179-87.

16 Lusk AC, Mekary RA, Feskanich D, Willett WC. Bicycle riding, walking, and weight gain in premenopausal women. Arch Intern Med 2010;170:1050-6.

17 Andersen LB, Schnohr P, Schroll M, Hein HO. All-cause mortality associated with physical activity during leisure time, work, sports, and cycling to work. Arch Intern Med 2000;160:1621-8.

18 Royal College of Physicians. How doctors can close the gap: tackling the social determinants of health through culture change, advocacy and education. Royal College of Physicians, 2010.

19 Department of Transport. Transport trends: 2009 edition. Department of Transport, 2009.

20 Department of Health and Department of Transport. Active travel strategy. Department of Health and Department for Transport, 2010.

21 Woodcock J, Edwards P, Tonne C, Armstrong BG, Ashiru O, Banister D, et al. Public health benefits of strategies to reduce greenhouse-gas emissions: urban land transport. Lancet 2009;374:1930-43.

22 Hamer M, Chida Y. Active commuting and cardiovascular risk: meta-analytic review. Prev Med 2008;46:9-13.

23 Ogilvie D, Egan M, Hamilton V, Petticrew M. Promoting walking and cycling as an alternative to using cars: systematic review. $B M$ J 2004;329:763-6.

24 Higgins J, Green S. Reviews including non-randomised studies. Cochrane handbook for systematic reviews of interventions 4.2.6. Wiley, 2006.

25 Hemmingsson E, Udden J, Neovius M, Ekelund U, Rossner S. Increased physical activity in abdominally obese women through support for changed commuting habits: a randomized clinical trial. Int J Obes 2009;33:645-52.

26 Groesz LM. A conceptual evaluation of a school-based utilitarian exercise model [PhD thesis]. University of Texas at Austin, 2007.

27 Wilmink A, Hartman J. Evaluation of the Delft bicycle network plan: final summary report. Ministry of Transport and Public Works, Netherlands, 1987.

28 Troelsen J. Transport og sundhed: Odense-Danmarks Nationale Cykelby 1999-2002 [Transport and health: Odense-the National Cycling City of Denmark, 1999-2002] [Danish]. Ugeskrift for Laeger 2005;167:1164-6.

29 Troelsen J, Jensen S, Andersen T. Evaluering af Odense-Danmarks nationale cykelby [Evaluation of Odense-Denmark's national cycle city] [Danish]. Odense Kommune, 2004.

30 Sloman L, Cavill N, Cope A, Muller L, Kennedy A. Analysis and synthesis of evidence on the effects of investment in six cycling demonstration towns. Department for Transport and Cycling England, 2009. 
31 Rissel C, New C, Wen LM, Merom D, Bauman A, Garrard J. The effectiveness of community-based cycling promotion: findings from the Cycling Connecting Communities project in Sydney, Australia. Int J Behav Nutr Phys Act 2010;7:8.

32 Haq G, Whitelegg J, Cinderby S, Johnson D. Intelligent travel: personalised travel planning in the city of York. Stockholm Environmental Institute, 2004.

33 Marinelli P, Roth M. TravelSmart suburbs Brisbane: a successful pilot of a voluntary travel behaviour change technique. Australasian Transport Research Forum, 2002.

34 Travel awareness, publicity and education supporting a sustainable transport strategy in Europe (TAPESTRY). Viernheim Household Transport, 2003. www.max-success.eu/tapestry/www.eu-tapestry. org/.

35 Department for Planning and Infrastructure. Travel behaviour change program for the city of South Perth under the TravelSmart program: technical appendix. Department for Planning and Infrastructure, Government of Western Australia, 2003.

36 Socialdata Australia. Community survey and marketing campaign fo the South Perth TravelSmart project: report of the second evaluation. Department for Planning and Infrastructure, Government of Western Australia, 1999.

37 Socialdata Australia. Community survey and marketing campaign for the South Perth TravelSmart project: third evaluation report. Department for Planning and Infrastructure, Government of Western Australia, 2000.

38 Sustrans. TravelSmart Frome pilot project. Sustrans, 2002.

39 Sustrans. Unpublished technical report on TravelSmart Frome pilot project. Sustrans, 2002.

40 Sustrans. TravelSmart Gloucester pilot project. Sustrans, 2002.

41 Sustrans. Unpublished technical report on TravelSmart Gloucester pilot project. Sustrans, 2002.

42 Sustrans. TravelSmart Gloucester (Quedgeley) 2003-04: a report on the individualised marketing project funded through the Department for Transport's personalised travel planning demonstration programme. Sustrans, 2004.

43 Sustrans. Greater Nottingham TravelSmart (Lady Bay and the Meadows): a report on the individualised marketing project funded through the Department for Transport's personalised travel planning demonstration programme. Sustrans, 2004.

44 Sustrans. TravelSmart Sheffield (Hillsborough/Middlewood) 200304: a report on the individualised marketing project funded through the Department for Transport's personalised travel planning demonstration programme. Sustrans, 2004.

45 Socialdata Australia. Travel behaviour change program for parts of the Perth Metropolitan Area under the TravelSmart program 2001 to 2005. Final report: TravelSmart $₫$ households program, city of Melville. Socialdata Australia, 2004.

46 Sustrans. Bishopston TravelSmart: a report on the individualised marketing project funded through the Department for Transport's personalised travel planning demonstration programme. Sustrans, 2004.

47 Sustrans. Cramlington TravelSmart: a report on the individualised marketing project funded through the Department for Transport's personalised travel planning demonstration programme. Sustrans, 2004

48 Socialdata. Provision of services for individualised marketing pilot scheme for Kingston Council: final report. Institute for Transport and Infrastructure Research Ltd, 2004.

49 Socialdata, Sustrans. TravelSmart in Doncaster. Final report on the Individualised Travel Marketing Campaign in Bessacarr, 2006. Report for Miller Homes, Ben Bailey Homes and Doncaster Metropolitan Borough Council. Socialdata, Sustrans, 2007.

50 Socialdata, Sustrans. TravelSmart in East Inverness. Final Report on the individualised travel marketing campaign in Cradlehall, Smithton, Culloden and Balloch, 2007. Report for the Scottish Government and the Highland Council. Socialdata, Sustrans, 2008.

51 Socialdata, Sustrans. Lancashire TravelSmart Programme. Interim evaluation of stage 2.1 (Torrisholme). Report for Lancashire County Council. Socialdata, Sustrans, 2007.

52 Socialdata, Sustrans. Lancashire travel behaviour research baseline survey 2006: key findings on promoting cycling. Sustrans, 2006.

53 Socialdata, Sustrans. TravelSmart in Gloucester: Barton, Tredworth and White City. Final report for the individualised travel marketing programme 2005-06. Report for Gloucester City Council. Socialdata, Sustrans, 2006.

54 Cervero R. City CarShare: first-year travel demand impacts. Institute of Urban and Regional Development, University of California at Berkeley, 2002.

55 Cervero R, Creedman N, Pohan M, Pai M. City CarShare: assessment of short-term travel-behavior impacts. Institute of Urban and Regional Development, University of California at Berkeley, 2002.

56 Cervero R, Creedman N, Pohan M, Pai M, Tsai Y-H. City CarShare: assessment of intermediate-term travel-behavior impacts. Institute of Urban and Regional Development, University of California at Berkeley, 2002.

57 Hodgson F, May T, Tight M, Conner M. Evaluation of the MIST travel awareness campaign: 2. The before-and-after study. Traffic Eng Control 1998;39:103-12.

58 Shoup D. Evaluating the effects of cashing out employer-paid parking: eight case studies. Transport Policy 1997;4:201-16.

59 Shoup D. Evaluating the effects of parking cash out: eight case studies. Air Resources Board Research Division, California Environmental Protection Agency, 1997.

60 Khaw KT, Jakes R, Bingham S, Welch A, Luben R, Day N, et al. Work and leisure time physical activity assessed using a simple, pragmatic, validated questionnaire and incident cardiovascular disease and all-cause mortality in men and women: The European Prospective Investigation into Cancer in Norfolk prospective population study. Int J Epidemiol 2006;35:1034-43.

61 Pucher J, Dill J, Handy S. Infrastructure, programs, and policies to increase bicycling: an international review. Prev Med 2009;50 (suppl 1):106-25S.

62 Brög W, Erl E, Ker I, Ryle J, Wall R. Evaluation of voluntary travel behaviour change: experiences from three continents. Transport Policy 2009;16:281-92

63 Ogilvie D, Bull F, Powell J, Cooper A, Brand C, Mutrie N, et al. An applied ecological framework for evaluating infrastructure to promote walking and cycling: the iConnect study. Am J Public Health, in press.

64 National Institute for Health and Clinical Excellence. Physical activity and the environment: guidance on the promotion and creation of physical environments that support increased levels of physical activity. National Institute for Health and Clinical Excellence, 2008.

65 Giles-Corti B, Knuiman M, Timperio A, Van Niel K, Pikora T, Bull F, et al. Evaluation of the implementation of a state government community design policy aimed at increasing local walking: design issues and baseline results from RESIDE, Perth Western Australia. Prev Med 2008;46:46-54.

66 MRC Epidemiology Unit. Commuting and health in Cambridge. 2010. www.mrc-epid.cam.ac.uk/Research/Studies/Commuting/.

67 De Hartog J, Boogaard H, Nijland H, Hoek G. Do the health benefits of cycling outweigh the risks? Environ Health Perspect 2010;118:8

68 Heelan KA, Donnelly JE, Jacobsen DJ, Mayo MS, Washburn R, Greene L. Active commuting to and from school and BMI in elementary school children-preliminary data. Child Care Health Dev 2005;31:341-9.

69 Van Sluijs E, Fearne V, Mattocks C, Riddoch C, Griffin S, Ness A. The contribution of active travel to children's physical activity levels: cross-sectional results from the ALSPAC study. Prev Med 2009;48:519-24.

70 Mutrie N, Carney C, Blamey A, Crawford F, Aitchison T, Whitelaw A. "Walk in to work out": a randomised controlled trial of a self help intervention to promote active commuting. J Epidemiol Community Health 2002;56:407-12.

71 Wen LM, Kite J, Rissel C. Is there a role for workplaces in reducing employees' driving to work? Findings from a cross-sectional survey from inner-west Sydney, Australia. BMC Public Health 2010;10:50.

72 National Institute for Health and Clinical Excellence. Workplace health promotion: how to encourage employees to be physically active. National Institute for Health and Clinical Excellence, 2008.

73 Hosking J, Macmillan A, Connor J, Bullen C, Ameratunga S. Organisational travel plans for improving health. Cochrane Database Syst Rev 2010;3:CD005575.

74 Craig P, Dieppe P, Macintyre S, Michie S, Nazareth I, Petticrew M. Developing and evaluating complex interventions: the new Medical Research Council guidance. BMJ 2008;337:a1655.

Accepted: 13 August 2010 